\title{
MODEL AKTIVITAS GERAKAN LITERASI BERBASIS KOMUNITAS DI SUDUT BACA SOREANG
}

\author{
Andri Yanto ${ }^{1}$, Saleha Rodiah $^{2}$, Elnovani Lusiana ${ }^{3}$ \\ ${ }^{1,2,3}$ Program Studi Ilmu Perpustakaan Universitas Padjadjaran \\ 12andriyanto@unpad.ac.id, ${ }^{2}$ saleha.rodiah@unpad.ac.id, ${ }^{3}$ elnovani.lusiana@unpad.ac.id
}

\begin{abstract}
One of the literacy movements that is currently developing is the proliferation of various communities Taman Bacaan Masyarakat (TBM) which was established by the community to provide access to information to the public in order to realize lifelong learning. Sudut Baca Soreang (SBS) as a TBM by relying on a variety of community is very active in making various activities literacy movements. This study aims to create a model of literacy movement activities undertaken by SBS with the end result was the model of a community -based literacy movement activities so that it can be one model for other TBM in making various activities literacy movements. The research method used in this study is a qualitative research using case study approach. The results showed that the shape of the literacy movement activities SBS driven by volunteers as well as spearhead in carrying out various activities that have been prepared weekly / monthly / yearly with one of the volunteers as person in charge. All activities are always evaluated regularly. This model can move literacy activities, promotional activities and drives the field of literacy advocacy activities. The manager of SBS (founders, trustees and volunteers) to make a wide range of activities aimed at local communities, which involves internal SBS as well as external parties SBS from local communities, students and community leaders and other strategic partners as a driver of literacy programming that has been designed by the manager of SBS, All activities that have been implemented are supported by promotional efforts through social media such as facebook as a primary medium.
\end{abstract}

Keyword: Activity, literacy movement, community.

ABSTRAK - Salah satu gerakan literasi yang saat ini berkembang adalah menjamurnya berbagai komunitas Taman Bacaan Masyarakat (TBM) yang didirikan oleh masyarakat untuk memberikan akses informasi kepada masyarakat guna mewujudkan pembelajaran sepanjang hayat.
Sudut Baca Soreang (SBS) sebagai sebuah TBM dengan mengandalkan berbagai komunitas masyarakat sangat aktif dalam membuat berbagai kegiatan gerakan literasi. Kajian ini bertujuan untuk membuat model aktivitas gerakan literasi yang dilakukan oleh SBS dengan hasil akhirnya adalah adanya model aktivitas gerakan literasi berbasis komunitas sehingga dapat menjadi salah satu percontohan bagi TBM lainnya dalam membuat berbagai kegiatan gerakan literasi. Metode penelitian yang akan digunakan dalam penelitian ini adalah kualitatif dengan pendekatan studi kasus. Hasil penelitian menunjukkan bahwa bentuk aktivitas gerakan literasi SBS dimotori oleh relawan serta menjadi ujung tombak dalam melaksanakan berbagai kegiatan yang telah disusun setiap minggu/bulan/tahunan dengan salah seorang sukarelawan sebagai penanggungjawabnya. Seluruh aktivitas tersebut selalu dilakukan evaluasi secara rutin dan dilakukan evaluasi tahunan pula. Model ini dapat menggerakkan aktivitas literasi, promosi kegiatan dan menjadi penggerak kegiatan advokasi bidang literasi. Para pengelola SBS (pendiri, pengurus dan relawan) membuat berbagai aktivitas yang ditujukan untuk masyarakat sekitar yang melibatkan pihak internal SBS maupun pihak ekternal SBS mulai dari masyarakat sekitar, pelajar ataupun tokoh masyarakat dan mitra strategis lainnya sebagai penggerak kegiatan literasi yang telah dirancang oleh pengelola SBS. Seluruh aktivitas yang telah dilaksanakan didukung oleh upaya promosi melalui media sosial berupa facebook sebagai media utama.

Kata Kunci: Aktivitas, gerakan literasi, komunitas.

\section{PENDAHULUAN}

Program pemerintah dalam rangka meningkatkan minat dan budaya baca masyarakat 
salah satunya adalah dengan mendirikan TBM (Taman Bacaan Masyarakat). Berdasarkan rilis pada laman Ditjen Paudni bahwa, pada awalnya TBM didirikan bertujuan untuk memfasilitasi masyarakat yang telah "melek aksara" agar tidak "buta aksara" kembali dengan memanfaatkan TBM sebagai sarana dalam memenuhi kebutuhan akan bahan bacaan yang memadai. Namun juga sebagai kebutuhan masyarakat akan bahan bacaan, tempat meminjam, dan menemukan informasi yang murah, layak, dan nyaman (Kemendikbud, 2014).

Menurut Juknis Program Penguatan Taman Bacaan Masyarakat yang diterbitkan Dirjen PAUDNI bahwa Taman Bacaan Masyarakat (TBM) adalah sebuah tempat/wadah yang didirikan dan dikelola baik oleh masyarakat maupun pemerintah dalam rangka penyediaan akses layanan bahan bacaan bagi masyarakat sekitar sebagai salah satu sarana utama dalam perwujudan konsep pembelajaran sepanjang hayat untuk mendukung peningkatan kualitas hidup masyarakat sekitar TBM (Kemendikbud, 2014). Tujuan mulia dari adanya TBM adalah pembelajaran sepanjang hayat untuk mendukung peningkatan kualitas hidup masyarakat.

Sesuai dengan amanah UU No. 43 Tahun 2007 tentang Perpustakaan bahwa, "pemerintah menjamin kelangsungan penyelenggaraan perpustakaan sebagai pusat sumber belajar masyarakat dan menjamin ketersediaan layanan perpustakaan secara merata di tanah air". Namun sampai saat ini masih belum sampai pada kondisi yang ideal. Kemudahan akses akan sumber belajar masyarakat masih sangat minim yang diberikan oleh pemerintah kepada masyarakat sebagai tanggungjawab dari pemerintah.

Hal ini memicu bermunculannya berbagai gerakan literasi yang bukan berasal dari pemerintahan melainkan dari komunitas masyarakat atau individu dari masyarakat tersebut. Rekomendasi penelitian dari tesis Håklev menyatakan bahwa, 100\% TBM pemerintah tidak memiliki kegiatan lain selain meminjamkan buku-buku, sedangkan salah satu dari pesan penting penelitian ini adalah keberhasilan TB (Taman Bacaan) lebih mirip pusat kegiatan menyeluruh daripada sekedar gudang buku (tempat menyimpan buku-buku) (Håklev, 2008).

TBM sebagai bagian dari gerakan literasi saat ini bukan hanya menjadi domain pemerintah melalui pengembangan atau penyelenggaraan berbagai perpustakaan dan sejenisnya. Gerakan ini juga mulai berkembang menjadi gerakan literasi yang bersumber dari gerakan komunitas masyarakat di suatu lokasi tertentu ataupun adanya bantuan dari berbagai perusahaan melalui Tanjungjawab Sosial Perusahaan (Corporate Social Responsibility-CSR) dalam mendirikan berbagai perpustakaan, TBM, Rumah Pintar dan berbagai sebutan lainnya yang pada intinya memberikan akases sumber belajar bagi masyarakat.

Menurut Håklev dalam penelitian yang dia lakukan bahwa, menjamurnya perpustakaan komunitas dimulai sejak tahun 2001 dengan sebutan taman bacaan (reading gardens) (Håklev, Factors that Contributed to the Community Library Movement in Indonesia, 2010). Adanyanya perpustakaan komunitas dengan 
sebutan TBM sebagai bentuk ketidakpuasan kelompok masyarakat atas penyelenggaraan TBM yang telah digulirkan pemerintah. Berdasarkan kondisi yang dipaparkan di atas, kami peneliti ingin mengetahui bagaimana model TBM yang dikembangkan oleh komunitas dengan dukungan relawan militan yang menjadi alternatif bagi kelompok masyarakat dalam pembelajaran sepanjang hayat untuk mendukung peningkatan kualitas hidup masyarakat itu sendiri.

Komunitas masyarakat dengan cara swadaya pada awal berdirinya tanpa adanya bantuan dari pemerintah mendirikan TBM sebagai gerakan literasi lokal. Salah satu komunitas TBM yang sangat tinggi aktivitasnya dan militansi dalam dalam gerakan literasi di masyarakat adalah Sudut Baca Soreang yang ada di Soreang Kabupaten Bandung (SBS). SBS berkomitmen memperbanyak ases informasi dan membuka partisipasi masyarakat dalam pemumbuhan budaya baca dengan memprakarsai Gerakan Soreang Membaca! (GSM!) berupa Gerakan Kabupaten Bandung Membaca (Kabaca!) (Riani \& Cayaraya, 2012).

SBS juga memiliki kegiatan peningkatan kualitas hidup masyarakat dengan berbagai aktivitas yang dilakukan sehingga mampu menciptakan kemandirian warga seperti peningkatan skills anggotanya sehingga dapat meningkatkan kualitas hidupnya melalui kemampuan kewirausahaan dengan skills yang dimilikinya. Sehingga dalam penelitian ini difokuskan kepada bagaimana model aktivitas gerakan literasi yang dilakukan oleh Sudut Baca Soreang?.

\section{TINJAUAN PUSTAKA}

Penelitian yang dilakukan oleh Stian Håklev pad a tahun 2010 yang berjudul Community Libraries in Indonesia: a Survey of Government-Supported and Independent Reading gardens menunjukkan bahwa perpustakaan umum yang sederhana dikenal dengan nama Taman Bacaan (TB) (Håklev, Community Libraries in Indonesia: a Survey of Government- Supported and Independent Reading gardens, 2010). Lokasi mereka sering di rumah seseorang atau di dalam sebuah bangunan umum, dan menyediakan akses yang mudah dan bersifat informal untuk koleksi bahan pustakan dan banyak kegiatan-kegiatan literasi.

Sejarah tentang TB mulai dari masa persewaan buku oleh keturunan Cina di abad 19, melalui Balai Pustaka dan pergerakan perpustakaan umum di masa pemerintahan Soekarno. TB modern mulai muncul di tahun 1980, lalu pemerintah mencoba menerapkan TB berskala besar di tahun 1990, dan pada akhirnya pergerakan masyarakat muncul di tahun 2001 secara independen. Berdasarkan wawancara dengan para sumber informasi, artikel-artikel di surat kabar, blog dan milis serta laporan NGO dan pemerintah, menunjukkan sejumlah faktorfaktor yang dapat dan mendukung pergerakan tersebut, yaitu: inspirasi tokoh teladan, "perpustakaan kasus terbaik", jejaring (networking) serta peran Islam dan nasionalisme.

Hasil statistik pemerintah dan hasil survei yang dilakukan di Jakarta, menunjukkan ada tiga jenis TB, yaitu: TB yang dibentuk oleh pemerintah nasional, regional dan daerah, TB yang didanai oleh donor berskala-besar, dan TB 
independen yang didirikan oleh masyarakat setempat.

Penelitian tentang gerakan literasi dengan dukungan relawan yang militan dan inisiator yang totalitas khususnya gerakan berbasis komunitas tanpa adanya dukungan dari pemerintah dalam pendiriannya masih sangatlah terbatas. Kebanyakan penelitian hanya fokus pada aktivitas dari gerakan literasi itu sendiri dan evaluasi program literasi informasi yang ada di TBM atau perpustakaan. Diharapkan dalam penelitian ini dapat mengungkapkan berbagai fakta menarik bagaimana tentang pendirian komunitas literasi sebagai gerakan yang swadaya dari masyarakat.

Gerakan literasi berbasis komunitas belum sepenuhnya dikaji dari sisi model aktivitas gerakan yang berbasis komunitas. Ini juga yang menjadi catatan pendiri Sudut Baca Soreang yaitu Agus Munawar yang menyatakan bahwa 'beragam kegiatan kreatif, rekreatif, yang diselenggarakan sebuah Taman Bacaan Masyarakat (TBM), dibelakangnya tidak terlepas dari kesediaan sekelompok masyarakat (relawan) yang rela berkorban (Anggadhitya \& Dinar, 2014).

Pendekatan penelitian untuk menjawab berbagai pertanyaan penelitian diatas adalah studi kasus. Pendekatan ini fokus kepada bagaimana mendapatkan pemahaman secara mendalam tentang suatu entitias atau peristiwa pada kurun waktu tertentu. Tipologi yang digunakan dalam penelitian studi kasus menggunakan tipologi "single case" atau kasus tunggal di mana hanya fokus kepada aktivitas gerakan literasi berbasis komunitas di Sudut Baca Soreang.
Melalui pendekatan ini diharapkan dapat memperoleh model aktivitas gerakan literasi yang berbasis komunitas mulai dari aktivitas gerakan literasi, aktivitas relawan, promosi dan kemitraan dalam gerakan literasi dengan tujuan pembelajaran sepanjang hayat untuk mendukung peningkatan kualitas hidup kelompok masyarakat atau komunitas.

Menurut Ahmed dalam Marihesya dampak dari adanya perpustakaan komunitas adalah:

1. library support community to be aware of national/regional issue

2. library creates community to find opportunity

3. library helps community to improve literacy rate

4. library sticking up student to pass their examinations

5. library helps generating new skills then organizing local business

6. library support to self improvement

7. library contribute to expand community knowledge (Marihesya, 2012)

Marihesya menyatakan bahwa "main activity based of community library is how to manage community intelligence and knowledge, not just develop the quantity of collection nor make up the building" (Marihesya, 2012). Aktivitas utama dari perpustakaan komunitas atau TBM bukan hanya pengembangan jumlah koleksi perpustakaan ataupun bangunan itu sendiri, melainkan bagaimana mengelola pengetahuan dan kecerdasan masyarakat.

Salah satu entitas penting untuk gerakan literasi mulai dari kegiatan membaca adalah adanya TBM. Menurut Sutarno NS (2006) 
bahwa Taman Bacaan Masyarakat mempunyai tanggung jawab, wewenang, dan hak masyarakat setempat dalam membangunnya, mengelola dan mengembangkannya (Sutarno, 2006). Dalam hal ini perlu dikembangkan rasa untuk ikut memiliki (sense of belonging), ikut bertanggung jawab (sense of responsibility) dan ikut memelihara. Seluruh aktivitas TBM sangat bergantung pada keterlibatan masyarakat itu sendiri.

Peran masyarakat sangatlah kental dalam aktivitas TBM, seperti yang tercantum dalam Juknis Program Penguatan Taman Bacaan Masyarakat yang diterbitkan Dirjen PAUDNI Kemdikbud bahwa TBM yang didirikan dan dikelola baik oleh masyarakat dalam rangka penyediaan akses layanan bahan bacaan bagi masyarakat sekitar sebagai salah satu sarana utama dalam perwujudan konsep pembelajaran sepanjang hayat untuk mendukung peningkatan kualitas hidup masyarakat sekitar.

\section{METODE PENELITIAN}

Metode penelitian yang akan digunakan dalam penelitian ini adalah kualitatif dengan pendekatan studi kasus, pemilihan metode penelitian kualitatif dengan pendekatan studi kasus sesuai untuk meneliti tentang Model Aktivitas Gerakan Literasi Berbasis Komunitas di Sudut Baca Soreang.

Penentu dari sebuah studi kasus adalah keinginan peneliti untuk secara khusus mengungkapkan permasalahan yang berkaitan dengan satu entitas tertentu, dengan memperhatikan konteks khusus dari keberadaan entitas tersebut (Pendit, 2003). Dalam hal ini entitas dalam penelitian ini adalah sebuah komuitas yang bernama Sudut Baca Soreang.

Studi kasus menurut Cavaya dalam Pendit dari segi tujuan penelitian ditujukan untuk mengungkapkan secara rinci sebuah fenomena dan atau mengembangkan teori baru yang cenderung menggunakan metode penelitian kualitatif. Tipologi yang digunakan dalam penelitian studi kasus menggunakan tipologi "single case" atau kasus tunggal di mana hanya fokus kepada gerakan literasi berbasis komunitas di Sudut Baca Soreang (Pendit, 2003).

Penelitian ini mempunyai pokok pertanyaan berkenaan dengan bagaimana model aktivitas gerakan literasi berbasis komunitas yang dilakukan pada kelompok Sudut Baca Soreang (SBS) di Kabupaten Bandung. Kasus yang dipelajari adalah aktivitas gerakan literasi berbasis komunitas di SBS berkaitan dengan upaya peningkatan pembelajaran sepanjang hayat untuk mendukung peningkatan kualitas hidup masyarakat.

\section{HASIL DAN PEMBAHASAN}

Dari hasil pengamatan di lapangan dan wawancara dengan informan serta studi dokumentasi diperoleh hasil bahwa aktivtas gerakan literasi sangat bergantung pada aktivitas yang dibuat oleh SBS dengan dukungan relawan yang ada. Seluruh kegiatan SBS telah tersusun dan terencana mulai dari kegiatan mingguan, bulanan dan tahunan dengan sasaran pemuda (anak-anak) dan pelajar, perempuan dan UMKM sebagaimana hasil wawancara dengan AM, sebagai pendiri SBS, yaitu: 
“... SBS ini lahir dari serangkaian kegiatan. Jadi bukan kemudian, bukunya siap segala macemnya siap, hey sodarasodara, masyarakat kesini saya sudah buka taman bacaan masyarakat. Tidak. Jadi TBM ini didirikan dari semangat untuk berbagi, mendekatkan buku kepada masyakat dengan apa yang kita punya" (Munawar, 2015)

Tujuan dari adanya SBS ini seperti yang diharapkan pendiri SBS adalah "menjadikan taman bacaan ini sebagai pusat berkegiatan masyarakat untuk berbasis teknologi informasi dan komunikasi dan bahan bacaan yang ada untuk meningkatkan kualitas hidup masyarakat". Sedangkan target pembaca dari SBS juga beberapa dari kalangan pelajar seperti yang dikemukakan Pengurus Harian SBS yaitu: kegiatannya kegiatan sudut baca aja cuman mengundang anak-anak, disini kan deket sama SMK, jadi di SMK, SMA (Ohh..) SMP gitu jadi ada kegiatan itu (F, 2015).

Berbagai aktivitas pengunjung SBS yang peneliti peroleh melalui laman akun facebook SBS, adapun sebagian kecil kegiatan yang dapat digambarkan melalui foto-foto yang diambil melalui laman https://www.facebook.com/ sudutbaca soreang, yaitu:

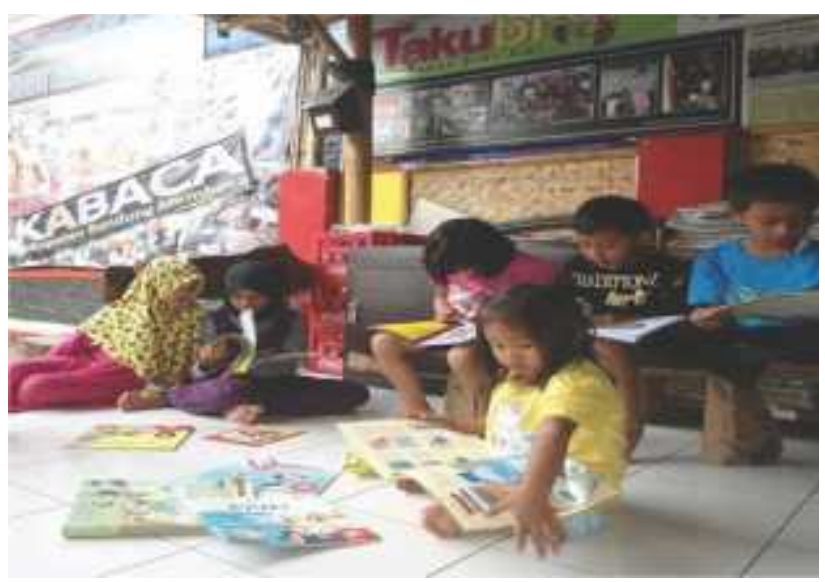

Gambar 1. Pengunjung Anak-anak dari sekitar lokasi SBS

Sumber pada website:

https://www.facebook.com/, 7 Juni 2014 di SBS

Kegiatan lainnya untuk anak-anak sekitar adalah Kegiatan "Wisata IT" seperti yang dimuat di laman facebook SBS anak sebelum bermain game edukasi "Paket Kemadirian" mulai dari Aku Berani Sendiri, Aku Senang Sekolah, Aku Gak Takut ke Dokter dan Aku Baik Banget wajib terlebih dahulu membaca koleksi yang ada di SBS.

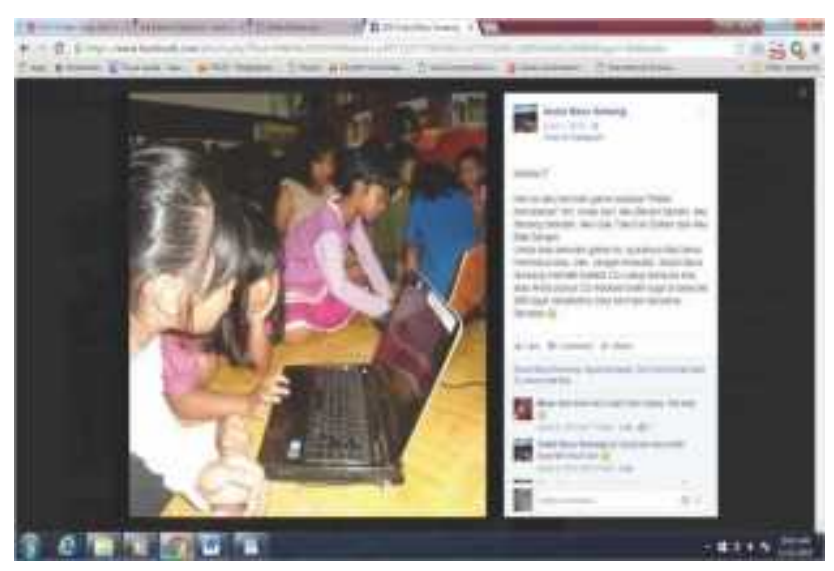

Gambar 2. Aktivitas Anak-Anak di SBS

Sumber pada website:

https://www.facebook.com/, 7 Juni 2014,

Beberapa kegiatan yang inisiatornya dimulai dari relawan seperti yang dilakukan oleh relawan EB mulai dari kelas prosa, kelas puisi dan kelas menulis. Hal ini berdasarkan hasil wawancara, observasi serta studi dokumentasi yang ada. Seperti pernyataan yang dilontarkan oleh relawan EB yaitu:

"Di kelas menulis itu. Memang a.. kadangkadang kita seleksi alam dulu ya, apapun gitu. Dari 20 yang pertama tadi, 4, yang bertahan 4 orang. [...] Kita puisi dulu, 
karena puisi itu yang bikin jadi dasar penulisan. Kalau mereka sudah a.. untuk menyeleksi kata atau kalimat. Kesananya, insya allah, bikin prosa bisa lebih bagus" (EB, 2015).

Hal tersebut dikuatkan oleh pengelola harian SBS bahwa SBS telah melaksanakan berbagai pelatihan sastra dan Teknologi Informasi dan Komunikasi (TIK) berdasarkan penyataan F, yaitu: "Kita sudah membikin pelatihan sastra berbasis TIK” (F, Pelatihan di TBM SBS, 2015).

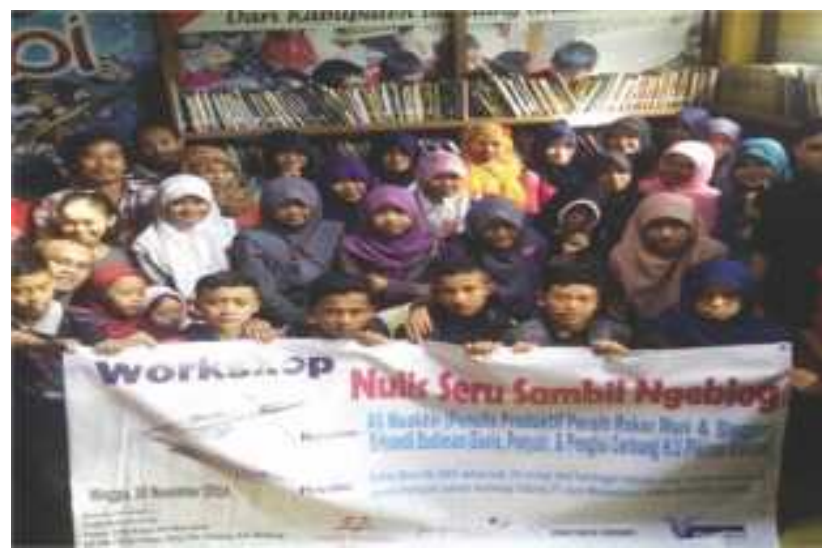

Gambar 3. Kegiatan Workshop Nulis Seru

sambil Ngeblog (Berbasis TIK)

Sumber pada website:

https://www.facebook.com/, 30 November 2014 di SBS

Kegiatan lainnya adalah diperuntukkan bagi warga sekitar SBS dimana banyak kegiatan yang memanfaatkan momentum hari besar atau jadwal-jadwal rutin yang ada di masyarakat sekitar.

Aktivitas yang ada juga diusahakan memberi nuansa menyenangkan dan tidak menyerampakn dengan berbagai peraturan yang ketat dikarenakan beragamnya pengunnjung SBS. Mulai dari pelajar, anak yatim piatu dan anak- anak usia dini yang masih memerlukan edukasi lebih lanjut. Hal ini berdasarkan wawancara dengan Ketua Harian SBS seperti berikut:

"Kadang-kadang disini anak-anak yayasan juga kalo mereka kan sedikit mungkin rada ini ya kurang ke kontrol juga sama orang tuanya. Suka kesini kadang-kadang mereka nggak pake sendal, jadi diedukasi. Cuci kakinya dulu gitu. [...] Jadi.. yah cobalah ngerangkul mereka. [...] Jadi perpustakaan(SBS) itu imaje-nya nggak nyeremin lah gitu kan. [...] Nggak tau nih kalo misalkan perpustakaan orang lain mungkin mereka takut juga gitu, nggak pake sendal, kotor-kotoran gitu. [...] Jadi perpustakaan yah jadi taman bacaan ini yah jadi gaul lah. Gitu. Jadi perpustakaan gaul lah, jadi perpustakaan yang anak muda. Karena kan kegiatan-kegiatan juga kita ngerangkum apa [...] komunitaskomunitas juga, gitu" (F, Pelatihan di TBM SBS, 2015).

Lebih lanjut narasumber menyatakan bahwa aktivitas yang ada di SBS memfasilitasi berbagai komunitas-komunitas yang ada dengan dukungan relawan. Seperti relawan yang ahli bidang penulisan sastra dan pelukis. Seperti yang dinyatakan F:

"Disini kan ada Kang Eri. Kang Eri ini penulis, kemaren sempet terbit kan tulisannya, cerpennya itu di taro PR[...]Ini Toleng, relawan disini juga. Dia lukis, dia ngebuka kelas lukis" (F, Pelatihan di TBM SBS, 2015).

Berdasarkan wawancara dan FGD dengan pendiri SBS bahwa TBM merupakan lembaga yang melayani masyarakat untuk mendapat layanan informasi dan harus dikenal oleh masyarakat. Seperti yang diungkap AM, yaitu:

"[...] idealnya memang lembaga layanan yang ada di masyarakat. TBM, Perpustakaan atau apapun namanya 
memang harus familiar sehingga orang mau datang ke tempat kita. Jadi, kata kuncinya memang kita harus bener harus baik gitu kan [...]“ (Munawar, 2015).

Menurut Kalida,masyarakat yang berkunjung ke TBM tidak harus memakai sepatu, tidak harus berbaju necis. Mungkin juga bisa tidak usah mendaftar sebagai anggota terlebih dahulu dan menjadikan TBM sebagai tempat yang humanis.

TBM mampu menjadi solusi bagi masyarakat yang ada dan lebih humanis (Kalida, 2012).

Berdasarkan hasil dokumentasi juga diperoleh hasil bahwa berbagai aktivitas yang ada di SBS seperti pelatihan TIK dan penyediaan fasilitas komputer untuk belajar untuk para pengunjung membuat salah seorang anggotanya menjadi wirausahawan muda untuk cutting sticker. Seluruh aktivitas di SBS harus dimulai dengan kegiatan membaca terlebih dahulu dan diarahkan untuk membaca, seperti yang diungkapkan oleh ketua harian SBS, yaitu, "Untuk baca sih, memang kami selalu nekanin, memulai segala aktifitas itu membaca dulu" (F, Kegiatan TBM SBS, 2015).

TBM memiliki fungsi sebagi sumber belajar bagi masyarakat, tempat yang memiliki sifat rekreatif melalui bahan bacaan, memperkaya pengalaman dan penumbuhan kegiatan belajar masyarakat, bahkan bisa berfungsi sebagai wahana pengembangan life skills (Kalida, 2012). Lebih lanjut TBM merupakan lembaga yang menjadi fasilitator masyarakat dalam pengembangan diri dan pengembangan kelompok-kelompok masyarakat, terutama bergerak dalam meningkatkan budaya baca masyarakat.
Menurut Kalida, bahwa perpustakaan komunitas yang berdiri di tengah-tengah perkampungan, merupakan bentuk sebuah kebutuhan masyarakat. Pendekatan dalam pembangunan dan pengembangan perpustakaan semacam ini, pada umumnya adalah oleh masyarakat atau komunitas itu sendiri (Kalida, Capacity building perpustakaan, 2015).

Lebih lanjut Kalida menjelaskan bahwa, pengelola perpustakaan tidak hanya fokus kepada manajemen pengelolaan koleksi bahan pustaka, namun juga pada penguatan dan pengembangan secara kelembagaan (capacity building), pengelola dituntut kreatif dalam menciptakan event bagaimana teknik dan strategi untuk meningkatkan minat hadir masyarakat ke perpustakaan (Kalida, Capacity building perpustakaan, 2015).

Berdasarkan hasil wawancara dengan narasumber, observasi lapangan, FGD dan studi dokumentasi dan pustaka dapat ditarik simpulan bahwa seluruh aktivitas yang ada di SBS sepenuhnya mengandalkan berbagai aktivitas literasi dengan beragam strategi dan pendekatan kepada masyarakat. Aktivitas yang dilakukan melibatkan masyarakat sekitar, para relawan, para pelajar yang ada di sekitar wilayah tersebut serta berbagai mitra SBS. Seluruh aktivitas yang ada disusun secara terencana dan melibatkan berbagai komponen masyarakat yang ada di sekitar. Seperti yang diungkapkan oleh AM, bahwa:

"soal mekanisme dan merencanakan aktifitas, kita suka ngumpul merencanakan program. [...]. Jadi mekanismenya kita ada meeting, kemudian merencanakan siapa penanggung jawabnya, anggarannya 
berapa, biasalah pemetaan membuat program sampai membuat ini [...] proposal" (Munawar, 2015).

Serta SBS juga sudah banyak melakukan kegiatan advokasi seperti yang dinyatakan oleh AM, yaitu, "Jadi kita harus coba mengadvokasi para pihak untuk memberikan dukungan secara nyata terhadap gerakan ini” (Munawar, 2015).

Lebih lanjut AM menyatakan bahwa SBS saat ini sudah mulai fokus melakukan advokasi kepada para penggiat atau komunitas literasi lainnya yang ada di sekitar SBS maupun di luar wilayah Kabupaten Bandung, hal ini berdasarkan pernyataan AM bahwa, "terus SBS ini sudah menekankan sejak awal bukan lagi membesarkan dirinya, tapi SBS harus berbagi juga ke sesama pegiat literasi” (Munawar, 2015).

Berdasarkan hasil penelitian yang diperoleh maka dapat dibuatkan model aktivitas gerakan literasi di SBS. Adapun model aktivitas gerakan literasi yang ada di SBS seperti gambar di bawah ini:

\section{Model Aktivitas Gerakan Literasi SBS}

Berdasarkan model di atas diperoleh gambaran bahwa seluruh aktivitas yang ada di SBS sangat bergantung sekali dengan tokoh, pengelola dan relawan yang ada di SBS untuk membuat dan merencanakan berbagai program yang menjadi aktivtas SBS mulai dari kegiatan mingguan, bulanan dan tahunan. Seluruh aktivitas tersebut selalu dilakukan evaluasi secara rutin dan dilakukan evaluasi tahunan pula. Model seperti ini menjadi penggerak utama seperti yang tergambar, sehingga dapat menggerakkan aktivitas literasi, promosi kegiatan dan menjadi penggerak kegiatan advokasi bidang literasi.

Para pengelola SBS (pendiri, pengurus dan relawan) membuat berbagai aktivitas yang ditujukan untuk masyarakat sekitar yang melibatkan pihak internal SBS maupun pihak ekternal SBS mulai dari masyarakat sekitar, pelajar ataupun tokoh masyarakat dan mitra strategis lainnya sebagai penggerak kegiatan literasi yang telah dirancang oleh pengelola SBS. Seluruh aktivitas yang ada diupayakan sepenuhnya oleh SBS dengan prinsip kemandirian dan bagaimana melayani masyarakat secara optimal.

Seluruh aktivitas yang telah dilaksanakan didukung oleh upaya promosi melalui media sosial berupa facebook sebagai media utama disamping media sosial lainnya yang digunakan SBS untuk publisitas berbagai aktivitas yang dilakukan SBS.

Dari seluruh aktivitas yang ada serta berbagai pengalaman yang dilakukan dalam gerakan literasi menjadikan SBS banyak melakukan kegiatan advokasi mulai dari TBM yang ada di wilayah Kabupaten Bandung dan Kabupaten Bandung Barat serta wilayah Jawa Barat serta advokasi kepada relawan-relawan penggerak literasi.

\section{SIMPULAN}

Sesuai paparan hasil dan pembahasan di atas, maka dapat ditarik simpulan sbeagai berikut:

1. Bentuk aktivitas gerakan literasi dimotori oleh relawan dalam berbagai kegiatan yang disusun setiap minggu/bulan dengan salah seorang sukarelawan 
sebagai penanggungjawabnya. Seluruh aktivitas tersebut selalu dilakukan evaluasi secara rutin dan dilakukan evaluasi tahunan pula. Model seperti ini menjadi penggerak utama seperti yang tergambar, sehingga dapat menggerakkan aktivitas literasi, promosi kegiatan dan menjadi penggerak kegiatan advokasi bidang literasi

2. Para pengelola SBS (pendiri, pengurus dan relawan) membuat berbagai aktivitas yang ditujukan untuk masyarakat sekitar yang melibatkan pihak internal SBS maupun pihak ekternal SBS mulai dari masyarakat sekitar, pelajar ataupun tokoh masyarakat dan mitra strategis lainnya sebagai penggerak kegiatan literasi yang telah dirancang oleh pengelola SBS.

3. Seluruh aktivitas yang telah dilaksanakan didukung oleh upaya promosi melalui media sosial berupa facebook sebagai media utama disamping media sosial lainnya yang digunakan SBS untuk publisitas berbagai aktivitas yang dilakukan SBS.

\section{DAFTAR PUSTAKA}

KEMENDIKBUD. (2014). RETRIEVED MEI 2, 2015, FROM JUKNIS PENGUATAN TAMAN BACAAN MASYARAKAT: H T T P: //W W W.PA UDNI.KE M DIK BUD. G O.ID/ BINDIKMAS/SITES/DEFAULT/FILES/DOCUME NTS/ FILE S/TAMPILAN\%20BUK U\%20JUKNIS\%20PENGUATAN\%20TBMOK-14\%20MEI.PDF

Anggadhitya, R., \& Dinar, A. (2014). Relawan Bidik Celah: Cerita Seru Sudut Baca Soreang. Soreang: SBS Publishing.

EB. (2015, Mei). Kelas Menulis. (A. Yanto, Interviewer)

F. (2015, Mei). Kegiatan TBM SBS. (A. Yanto, Interviewer)

F. (2015, Mei). Pelatihan di TBM SBS. (A. Yanto, Interviewer)

Håklev, S. (2008). Håklev, S. Retrieved Mei 2, 2015, from Mencerdaskan Bangsa Suatu Pertanyaan Fenomena Taman Bacaan di Indonesia: https://tspace.library. u to ro nto . ca/b i tstream/1807/16623/1/ Me nc e r dask an $\% 20$ Bang sa\% $20-\% 20$ bahasa\%20indonesia2\%285\%29.pdf

Håklev, S. (2010). Community Libraries in Indonesia: a Survey of GovernmentSupported and Independent Reading gardens. Library Philosophy and Practice.

Håklev, S. (2010). Factors that Contributed to the Community Library Movement in Indonesia. Libri: International Journal Of Libraries \& Information Services, 15-26.

Kalida, M. (2012). Fundraising Taman Bacaan Masyarakat (TBM). Yogyakarta: Aswaja Pressindo.

Kalida, M. (2015). Capacity building perpustakaan. Yogyakarta: Aswaja Pressindo.

Marihesya, A. (2012). Al Faz Community Library: a Lighter after the Disaster. 15th General Conference of Congress of Southeast Asian Librarians (CONSAL XV) . CONSAL . 
Munawar, A. (2015, Mei). TBM SBS. (A. Yanto, Interviewer)

Pendit, P. L. (2003). Penelitian Ilmu

Perpustakaan dan Informasi: Suatu

Pengantar Diskusi Epistemologi dan Metodologi. Jakarta: JIP-FSUI.

Riani, D., \& Cayaraya, S. (2012). Sudut Baca Soreang: dari Kabupaten Bandung untuk Indonesia. Soreang: SBS Publishing.

Sutarno, N. (2006). Perpustakaan dan Masyarakat. Jakarta: Sagung Seto. 
